\title{
Aristoteles'in Epistemolojisinde Tümevarım ve Soyutlama İlkesi
}

\section{The Principle of Induction and Abstraction in Aristotle's Epistemology}

\author{
Rafiz Manafov, ${ }^{\mathrm{a},{ }^{*}}{ }^{2}$ Zehra Oruk ${ }^{\mathrm{b}}$ \\ ${ }^{\text {b }}$ Dr.Öğr.Üyesi, Muş Alparslan Üniversitesi, İslami İlimler Fakültesi, Felsefe ve Din Bilimleri, Muş/Türkiye. \\ ORCID: 0000-0003-0812-8554
}

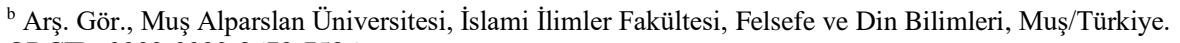
ORCID: 0000-0002-3673-7536

\begin{tabular}{l} 
MAKALE BİLGISİ \\
\hline Makale Geçmişi: \\
Başvuru tarihi: 13 Aralık 2019 \\
Düzeltme tarihi: 29 Ocak 2020 \\
Kabul tarihi: 26 Şubat 2020 \\
\hline Anahtar Kelimeler: \\
Töz, \\
Soyutlama, \\
Tümevarım, \\
Tikel, \\
Tümel
\end{tabular}

\section{ARTICLE INFO}

Article history:

Received 13 December 2019

Received in revised form 29 January 2020

Accepted 26 February 2020

\section{Keywords:}

Substance,

Abstraction,

İnduction,

Particular,

Universal

\section{ÖZ}

Günümüze kadarki düşünce sisteminin temellerini atan Aristoteles, varlık ve bilginin anlaşılması konusunda kendisinden önceki filozoflara nispetle daha sistemli bir yol izlemiştir. Aristoteles, önceki düşünürler gibi, tümel kavramını kabullenmiş, fakat bu kavrama yüklediği epistemik değer meselesinde onlardan ayrılmıştır. Aristoteles açısından bilim ve bilgi doğrudan tümel kavramlar ile bağlantılıdır, fakat tümeli elde etmenin yolu tikelden geçmektedir. Tikeller ve tümellerin temel özelliklerinin belirlenmesi ise soyutlama ve tümevarım sayesinde elde olunmaktadır. Bu nedenle de, her iki kavram Aristoteles epistemolojisi ve ontolojisi için vazgeçilmez öneme sahiptir. Biz de çalışmamızda, Aristoteles`in tümevarım ve soyutlama ilkelerini tözle ilişki bağlamında değerlendireceğiz.

\section{Giriş}

Herakleitos ile başlayan, sofistlerce alevlenen ontolojik değişim rüzgârı Platon'da Ay üstü âlemde duraksamış olsa da, Ay altı âlemde daha güçlü bir şekilde "esmeye" devam edince, Aristoteles'in karşısında acilen yapılması gereken şey, Ay altı âlemde varlığı dayandıracağı değişmez bir ilke bulmak olur. Doğan düşüncesinin iptali sonucuna götürecek diğer bir görüş de Elealılar'ın öğretisidir ki, onlar da varlığın değişmez, bölünmez ve hareketsiz olduğunu savunurlar. Oluş sorunu bu ilk filozofları tedirgin eder, zira onlar açısından "var" gibi görünen "şey", ne var olan bir şeyden ne de var olmayandan meydana gelebilir. Parmenides in değişme ve hareketi yadsımasından yola çıkarak öğrencisi Aristippos, sadece değişmenin değil, bir özneye kendisinden başka bir yüklemi yükleyen önermelerin bile imkânsızlığını savunacaktır (Arslan, 2017: 137). Buna karşın, doğa filozoflarının bir kısmı da, bütün diğer şeylerin, yoğunlaşma

\footnotetext{
* Sorumlu yazar/Corresponding author

e-posta: r.manafov@alparslan.edu.tr
} 
ve seyrekleşme ile kendisinden meydana geldikleri tek bir temel cisim (arkhe) olduğunu öne sürerken, kimi filozoflar onların hepsinin, içinde karşıtların bulunduğu tek bir kütleden çıktığını savunurlar (Ross, 2017: 111). Sokrates in ahlâkta bulduğu değişmez, mutlak ve tümel ilkeleri, Platon geometrik nesnelerde bulur fakat onu içinde yaşadığımız dünyaya değil, idealar dünyasına ait kılar.

Yunan düşüncesinde madde kavramını Aristoteles`in bulduğunu söylemek doğru olmasa da, maddi dünya düşüncesini ilk kez bilinçli ve kararlı bir şekilde reddeden ilk filozofun, Aristoteles in hocası Platon olduğunu söylemek yanlış olmaz (Arslan, 2017:136). Örneğin, Platon somut varlığın doğasının kavramsal açıklamasını yaptığı Timaios 'ta somut tikel varlıkları ele alırken, onlar hakkında kalıcılık ve daimilik gibi anlamlara gelecek "şu" ve "bu" kavramlarını kullanmak yerine, "şöyle", "şu doğaya sahip" gibi ifadelerle konuşulmasını doğru bulur. (Platon, 2015: 49d5).

$\mathrm{Bu}$ sorunlar 1şığında Aristoteles, varlığın değişken, geçici özelliklerinin yanı sıra değişmez olan bir tarafının da var olduğunu kanitlamak zorunda kalırken, diğer taraftan da varlıktaki değişimleri kabul edip, onların değişim ilkelerini belirlemesi gerekir. Fakat Aristoteles in değişimi ve oluşu açıklamak için başvuracağı madde kavramı, artık Doğa Filozoflarının madde kavramıyla aynı olmayacak, onu Yunan dünyasında görülmemiş bir biçimde ve orijinal şekilde tasarlayacaktır. Maddi olanı temellendirmek için gereken ilkeyi töz kavramında bulacaktır.

Aristoteles'in varlığa yaklaşım tarzı, kendinden önceki düşünürlerin de etkisiyle dış dünyadaki varlığa verdiği ontolojik statüye karşılık zihinsel olana verdiği epistemik değerin birlikte incelenmesi ile daha iyi anlaşılır. Bu durumun tabii sonucu olarak karşımıza zihinsel varlık ve zihin dışı yani hariçteki varlık şeklinde iki farklı varlık düzlemi ortaya çıkar. Ancak bahsi geçen bu iki varlık arasında menşei, sebebi ve varlığı itibari ile öncelik sonralık ilişkisi, onların varlığa gelme durumları, zihinsel olanın hariçte olandan $\mathrm{m}$ ı soyutlandığı, yoksa hariçte olanın zihinsel olan dolayısı ile mi varlığa geldiği gibi birçok soruya ve soruna yol açmaktadır. Aristoteles açısından bahsi geçen iki tür varlık arasındaki ilişkiyi açıklayabilmek için onun “öncelik" kavramına yaklaşımının ne olduğunun anlaşılması önemlidir.

\section{Aristoteles'te “Öncelik” Düşüncesi}

Aristoteles 'in eserlerinde birden fazla mecra için kullanılan "öncelik" kavramı insan zihninin normal işleyişi doğrultusunda zamansal bir önceliği çağrıştırır. Bu herhangi bir şeyin başka bir şeyden daha önce varlığa gelmesi gibi bir izlenim uyandırır. Sözgelimi, düğmeye basılır ve ardından kapı açılır. Düğmeye basma olayının kapının açılmasından önce gerçekleşmesi zamansal bir önceliktir. Bununla birlikte düğmeye basılması aynı zamanda kapının açılmasının sebebi olarak da karşımıza çıkar. Bu örnekte olduğu gibi "öncelik" kavramı birden fazla anlamda karşımıza çıktığı gibi birden fazla türü de mevcuttur. Özellikle bu kavram Aristoteles tarafindan ontolojik ve mantıksal öncelik olarak iki farklı şekilde değerlendirilmiştir.

\section{-Ontolojik Öncelik}

Tözsel önceliği temel alan bu yaklaşımda Aristoteles, bağımsız olarak var olma yeteneği ile başkalarına üstünlüğü olan varlıkların özelliklerini ifade eder (Aristoteles, 2019:588). Yani, buradaki öncelik, var olma konusunda başkasına ihtiyaç duymayan ve varlığı kendinden olan bir varlığın, var olmak için başka varlıklara gereksinim duyan varlıklardan daha "öncelikli" olmasıdır. Zira varlığı için başka varlıklara ihtiyaç duyan "şey" kaynağı itibari ile sonralığa mahkûmdur. Sözgelimi, ekmeğin olması için öncelikle buğdayın var olması gerekir. Dolayısıyla buğday, ekmekten öncedir. Ancak buğdayı da önceleyen tohum, tohumu önceleyen bașka varlıklar olmalıdır. Bu silsile bir yere kadar gider. Ve durması gereken yer, artık başka hiçbir şeyin kendisinin varlığına kaynaklık etmediği, ancak kendisinin başkasının varlığına doğrudan ya da dolaylı etki eden varlıktır. Bahsi geçen bu varlık ontolojik olarak hepsinden öncedir, önceliklidir.

\section{-Mantıksal Öncelik}

Bu tür öncelik ise diğer kavramların oluşturduğu bileşime dâhil olan varlıkların önceliğidir (Aristoteles, 2019:588). Bu şu anlama gelmektedir: Bir bileşim birden fazla kavram tarafından kurulur. Önermesel bir bütünü oluşturan kavramların bir araya gelmesi, o bileşimin oluşması için ön şarttır. Bu nedenle öncelikle kavramlar bulunmalı ve kavramların bir araya gelmesi bileşimi oluşturacağından, bu kavramlar bileşimi öncelemelidir. Dolayısıyla mantıksal açıdan düşünüldüğünde bu kavramlar, kendilerinden oluşan bütünü öncelerler.

Şunu belirtmek gerekir ki, bu öncelik ve sonralık durumu ontolojik varlıkların kendi içerisinde ve mantıksal olan zihinsel varlıkların da kendi içerisinde vukua gelen bir durumdur. Ancak burada asıl sorulması gereken şey şudur: "Zihinsel varlıklar ve dış dünyadaki varlıklar arasında bir öncelik-sonralık ilişkisi var mıdır?”. Bu soru bizi makalemizin esas amaçlarından olan soyutlama düşüncesine götürecektir. Ancak bundan önce Aristoteles açısından ontolojik öncelik ve akabinde epistemik öncelik irdelenmelidir. Nitekim ontolojik öncelikli olanın yani tözün neliği belirlenip, epistemik öncelikli olanın tespiti gerçekleşince, bu öncelikler arasındaki soyutlama dediğimiz ilişki daha anlaşılır kılınmış olacaktır. Böylece bilgi ve bilim için vazgeçilmez olan tümevarımın temel ilkeleri belirlenecektir.

\subsection{Aristoteles'te Ontolojik Öncelik / Platoncu Tümeller Eleştirisi}

Aristoteles'ten önceki filozoflarda da bulunan ancak yoğun bir şekilde Platon tarafından incelenmiş olan zihinsel olana ve hariçte bulunan maddi varlıklara tekabül eden kavramlar sırasıyla tümeller ve tikellerdir. Bu kavramlar Platon'un epistemolojisinin ve hatta ontolojisinin merkezinde yer alan idealara karşılık gelen varlık türüdür. Ona göre idealar, reel ve zihinsel varlıklar olup diş dünyadaki şeyler onların yansımasıdır ve Platon'un var olduklarını kabul ettiği tüm idealar bir olarak vardır. Bunlar en üstün cins olarak sunduğu varlıktan pay alırlar. Onun idealarının var olması duyusal nesnelerin gerçek manada varlık olma hakkını ellerinden alır. Zira ona göre asıl varlık idealar olup, tikellerden oluşan doğanın herhangi bir ontolojik değeri yoktur.

Aristoteles'in, Platon'un aksine, “varlık” kavramına yüklediği anlam birden fazladır. Nitekim ona göre Platon'un düşüncesinde olduğu gibi tek bir varlık değeri olup bunların da tüm idealarda olan bir niteliğe indirgeme düşüncesi doğru 
değildir (Arslan, 2017: 124). Zira o tözün yanında ikinci tözler dediğimiz özün de varlığını, akılsal-ideal varlık ile birlikte tözsel olan duyulur varlığı da kabul ederek gerçek anlamda daha elle tutulur bir varlık tanımı yapmaktadır.

Aristoteles duyulur olan doğanın varlığından asla kuşku duymaz, bu nedenle onu kanıtlamaya da çalışmaz ve bu konudaki herhangi bir kuşkuyu gülünç bulur. Çünkü doğa(1 nesneler) kendi aracılığıyla bilinir olanlardır (Aristoteles, 2019b: 53)Ona göre, madde her şeyden önce bir potansiyeldir. Kendisi bilinemez fakat olacağı, olması gereken şeye göre ancak tanımlanabilir ki, bu da özdür (ikinci dereceden töz). Potansiyel yani bil-kuvve olanın bilfiile dönüşmesi, sürecin hareketinin tek ve nihai özelliği değildir. Nitekim maddi varlıklar yani tikeller, dış dünyada varlığa gelmek ile kalmayıp sürekli bir değişim ve dönüşüm içindedirler.

Aristoteles`e göre, kendisinden önceki düşünürlerin iddia ettiği gibi, her şeyin aktığı bir ortamda şeylerin gerçekliği yoktur. "Şu" dediğimiz halde artık o, o olmaktan çıkar. Bu nedenle maddesel olan herhangi bir varlığın tikel anlamda tanımını yapmak bizatihi onun varlığına mutlak bir şekilde işaret etmez. Dolayısıyla oluş ve bozuluş dünyasında önerme de kurulamaz. Sürekli olan bu değişim içerisinde herhangi bir tikel, sözgelimi ahşap ya da tunç kendilerindeki değişmenin nedeni de olamazlar. Ne ahşap yatak yapar, ne de tunç heykel, bu durumda değişimin nedeni başka bir şeydir.

Platon'un idealar kuramını revize etmek maksadıyla Aristoteles'in önerdiklerinin başında hocasının her bir varlık için teklif ettiği ideaların sayısını azaltmak vardır. Bununla birlikte Platon'un iddia ettiği gibi her genel olan nitelik için idea yakıştırmasında bulunulmasını Aristoteles tasvip etmez. Ayrıca Platon'dan keskin bir şekilde ayrıldığı ideaların duyusal varlıklara içkin olduğu düşüncesini ileri sürerek, gerçek varlıklardan ayrı ve uzak, aşkın birer varlıklar olduğunu reddeder. Ona göre doğadaki oluş ve hareketin varlığa içkin ilkeleri olarak tümeller olayları açıklayıcı ilkelerdir (Arslan, 2017:127). Aristoteles, Platon tarafindan gökyüzüne çıkarılmış olan esas varlığın kaynağı şeklinde lanse edilen tümelleri "yere indirerek", dış dünyada gözlemlediğimiz varlıklara içkin kılar ve evrende gözlemlediğimiz hareketin, oluşları açıklamak için temel ilkeler olduğunu öne sürer.

Görüldüğü üzere Aristoteles tümeli inkâr etmemektedir. Ancak ona göre tümel, birden fazla varlığa yüklendiği için töz ol(a)maz. Çünkü ona göre tözleri yani mahiyetleri aynı olan varlıklar, bir ve aynı olan varlıklardır. Tümel de birden fazla varlığa yüklendiğinden şayet töz olmuş olursa, her bir varlığın aynı tözden oluşması anlamına gelecektir ki, bu da bahsi geçen varlıklar arasındaki çeşitliliği ortadan kaldırır. Hepsi bir ve aynı varlıklar olmuş olurlar. Ayrıca töz, bizatihi yüklem olamaz(Aristoteles, 2019a: 392). Kendisi epistemolojik olarak yani önermede konu, ontolojik olarak dış dünyada madde kabul edilir. Oysa tümeller yani ikincil tözler birer yüklemdir.

Tümellerin, töz olamamasının bir diğer gerekçesi ise kendisine yüklendiği özne itibari ile çokluk oluşturması yönünde olacaktır. Nitekim Aristoteles'e göre sözgelimi "insan", birey olarak insan tözünün kapsadığı bir şeydir. Aynı şekilde "hayvan" da kendisinin içinde bulunduğu hayvan tözüdür. "İnsan, hayvandır." dediğimiz takdirde insan ile hem tözü olan insan kastedilir, hem de kendisi de bir şeyin tözü olan "hayvan", insana yüklenmiş olur. Bu durumda birey olarak insanda birden fazla töz olmuş olur ki, bu ikiliğe yol açar. Oysa tözü itibari ile insan tektir ve aynı tözü paylaşan insanlar mevcut olduğundan bunların genel adı "insan" olmuştur. Bu açıdan düşünüldüğünde "hayvanlık" bir töz olamadığı gibi insanın da bir ögesi olamaz (Aristoteles, 2019a: 392-393).

Genel olarak bakıldığında, tanımı yapılan türlere yüklenen hiçbir şey başka herhangi bir şeyin de tözü olamazlar. Aynı zamanda varlıkta ortak olan yüklemlerden hiç biri kendi başına bir varlık değerine sahip değildir. Bunlar ancak kendisine yüklendiği şeyin niteliğidir (Aristoteles, 2019a: 393). Bu durumda bir şeyin niteliğinin onun tözü olduğunu söylemek de gereksizdir. Zira nitelik olarak ifade edilen tümelin kendisi bir şeye yüklenendir. Dolayısıyla herhangi bir varlık, tözsel bir çokluğu kabul etme istidadına sahip olmadığından tümellere "nitelik" yakıştırması daha uygundur. Böylece Aristoteles'in tözleri, türlere aittir denilirse yanlış ifade edilmiş olmaz. Zira türlerin her biri birer töze karşılık gelir ve bu tözler de türlerin altındaki fertlerin her birinde mevcuttur.

\subsection{Aristoteles'in Ontolojik Hiyerarşisi/Birinci Tözler ve İkinci Tözler}

Aristoteles tarafından tözün tanımı yapılırken, "bir konu hakkında ya da bir konu içinde onaylanmamış olandır" (Aristoteles, 2017: 23) şeklinde bir ifade kullanılır. Ona göre tözler ontolojik değer açısından birinci tözler ve ikinci tözler olarak iki türdür. Birinci töz yani cevher diğer kategorilerden herhangi biri olmamakla birlikte başka bir töze herhangi bir bağlantı ile ilişmeyendir. Yani türün altında sıralanmış olan herhangi bir ferde sıfat olmayacak ya da onun zamanına, uzamına, bir diğer ifade ile onu tanımlayacak ya da tasvir edecek herhangi bir haline ilişmeyen olacaktır. "İnsan" ya da "at" gibi. Bunlar birincil tözlerdir.

İkinci tözler ise, birinci tözler içinde yer alan türlere ve onlara eklenen cinslere denir. İkinci tözler konu hakkında onaylamayı da gerektirir (Aristoteles, 2017: 24). Sözgelimi insan ya da at birinci tözler olup onların türü olan "hayvan" ve bir üst basamakta yer alan "canlı" oluşu ikinci tözler olarak karşımıza çıkacaktır. Bir önermeyi oluşturan unsurlar konular ve yüklemlerdir. Konu, tikellerden yani tözlerden oluşurken, Aristoteles'e göre yüklem, isim ya da tanım için konuyla ilgili olarak (konu hakkında) onaylanmış olmalıdır. Bir konunun yüklemi ya dokuz kategoriden biri olarak ona ilişir ("insan, beyazdır" gibi) ya da tanım cümlelerinde olduğu gibi yakın fasıl, yakın cins/tür (insan düşünendir/ insan canlıdır) ile onu tanımlar. $\mathrm{Bu}$ konu ve yüklem ilişkilerinden her biri ya konudadır ya da konu hakkında onaylanmış olandır.

Diğer taraftan birey olarak insanı ele alalım. İnsan türünün ismi bahsi geçen fertte de bulunduğu gibi, o fert insanın karşıladığ 1 manaya da sahiptir. Tözsel hiyerarşiye baktığımızda (cins-tür-fert), Aristoteles'e göre töz olan fert olduğu için ikincil tözlerden tür, töze cinsten daha yakındır. Bu nedenle tür, cinsten daha fazla tözdür (Aristoteles, 2017: 24). Nitekim ilk töz dediğimiz ferdin doğasına yönelik yapılan bir beyanda, yakın cins yakın ayrım formülü ile önceliği türe veririz. "İnsan canlıdır ya da insan cisimdir." Evet, insan hem canlıdır hem cisimdir, ancak bu durumda 
insanın tözüne en yakın olan onun "cisim” oluşundan ziyade canlı olmasidır.

Aristoteles'e göre "ilk tözler, konu içinde olmadıkları gibi konunun yüklemi de değillerdir (Aristoteles, 2017: 26). Zira ilk tözlere cins ve tür yüklenebilirken, ilk tözler hiçbir konu hakkında onaylanmadıkları gibi herhangi bir konunun bölümü olmaktan da uzaktırlar. Örnekle ifade edecek olursak; fert olarak "Zeyd" ya da "at" herhangi bir konunun bölümü değillerdir. Zeyd dışında herhangi bir şeye "Zeyd'dir" diyemeyiz. Ancak onu belirterek "Bu Zeyd'dir." diyebiliriz. "Bu" işaret zamirinin yerine geçebilecek herhangi bir konu yoktur, olamaz. Zira Zeyd hiçbir konunun yüklemi ya da bölümü olamaz.

Bir konunun yüklemi olamayan ferdin yüklemi olan ikinci tözler de bir konunun bölümü olmazlar. Sözgelimi "insan" birey olarak alınan insanın yüklemidir. İsmi de aynı şekilde bu ferde yüklenir. Ancak tür olarak "insan" fert olan insanın bir bölümü değildir. Aynı durum canlı yani hayvan olan insan için de geçerlidir. Hayvan olması ona yüklenir ancak bölümü değildir. Bununla birlikte konunun içinde yer alan nesnelerin isimleri konuya yüklem olsa da tanımlarının konuya yükletilmesi olanaksızdır (Aristoteles, 2017: 26) *

Bununla birlikte bir cins, tür hakkında onaylanırken tam tersi olarak türü cinse yüklem yapamayız(Aristoteles, 2017: 25). Sözgelimi "İnsan, canlıdır." diyerek insan türü hakkında canlılık cinsini onaylasak da tam tersi şeklinde "Canlı, insandır." önermesi yanlış bir ifade olacaktır. Zira canlılık yalnızca insana yüklenmiş bir nitelik olmayıp, canlılar da insanlar ile sınırlandırılamaz. Tüm yüklemlerin konusu bireyler ya da türler olduğundan onlara yüklenmiş olan cinslerin tanımı ilk tözlere cinsler de türlere uygunluk gösterir (Aristoteles, 2017: 27). Dolayısı ile buradan da anlaşıldığı üzere niteliklerini töze göre belirleyen ikinci tözlere (Aristoteles, 2017: 28) birinci tözler olan tikellerin yüklenmeyeceği açıktır.

\section{Aristoteles Epistemolojisinde Mantıksal Öncelik}

Aristoteles varlık konusunda hocası Platon'dan farklı görüşler sunduğu gibi epistemik sisteminde de yer yer hocasından ayrı bir yol izler. Doğru(luk) kavramı da bunlardan biridir. Nitekim birinciye göre doğruluk ya da yanlışlık dediğimiz şey, bilgimize tekabül eden dış dünyadaki nesnenin gerçekliği ile ölçülür(Aristoteles, 2017: 30). Ona göre "Gerçekte o doğrudur" deyiminin "o vardır" ile aynı sıraya konması gerekir. (Aristoteles, 1989a: 117). Oysa Platon'da doğruluk tanımı nesnenin gerçekliği ile mutabakat şeklinde ele alınmaz.

Platon da diğer bazı rasyonalistler gibi bilginin verili olduğunu, zaten zihinlerimizde var olduğunu ve bunun sonucunda ona erişmenin sadece bir hatırlama ile gerçekleşebileceğini öne sürer. Dış dünyadaki varlıklara yani tikellere ontolojik bir değer vermeyen Platon, onlara epistemik bir değer vermeyi de uygun bulmaz. Oysa Aristoteles tarafindan bilginin bir hatırlanma olduğu reddedilir. O, bilgiye ulaşmak için tecrübeye başvurur.

Herhangi bir ilmin bilgisine ulaşmanın, müşahede yolu ile gerçekleştiğini ifade eden Aristoteles, bir ilme ait ilkeleri elde etmek için tecrübeyi göz önüne alır. Sözgelimi astronominin ilkelerini elde etmek için gök bulgularından hareket edilir ve astronomik olayların yeterince tecrübe edilmesi gerekir (Aristoteles, 1989a: 91). Buradan yola çıkarak bilginin elde edilmesi Aristoteles açısından Platon'un "hatırlama” yaklaşımının aksine- kesbidir.

Aristoteles varlık düşüncesinde olduğu gibi epistemoloji kuramında da Platon'a karşı çıkar. Platonun bilginin hatırlanma olduğu iddiasını içeren yaygın Menon diyaloğunun ifade ettiği bilgi yaklaşımını eleştirir ve şöyle der:

Gerçekte hiçbir zaman önceden hususi hakkında bilgi sahibi olunmaz; fakat tümevarım vaki olurken aynı zamanda hususi nesnelerin bilgisini elde ederiz ve bize sanki hatırlayıp da onları tanımışız gibi gelir. Bazı şeyler vardır ki biz onları, söz gelimi, bir üçgen olduğunu bilir bilmez, açıların iki dik açıya eşit olduğunu derhal biliriz. Bütün öbür haller için de bu böyledir (Aristoteles, 1989a: 177).

Aristoteles'in hususi olan ile kastettiği, tikellerin bilinmesinin tecrübe ile olması, bilginin idealar vasıtasıyla rasyonalist bir bakış açısı eşliğinde hâlihazırda zihinde bulunduğu düşüncesine karşı bir itirazdır. Nitekim ona göre hususinin bilgisi umumiye tabiidir. Hususi olanın bilinmesi onların kendilerine özgü bilgi ile değildir. Aristoteles'e göre tecrübeden elde edilen dışında tecrübe edilebilecek nesnelere karşı bilgimiz umumi, ilim ve has ilim dışında mevcut değildir (Aristoteles, 1989a: 178)**

Aristoteles'in Menon'a yönelttiği bahsi geçen eleştiride, Sokrates 'in dili ile Platon'un bizlere sunduğu asıl ve gerçek bilginin ideaların bilgisi olduğu ve Sokrates'in de ifade ettiği gibi bu bilginin zaten bizim zihnimizde olduğu yaklaşımıdır. Nitekim Menon'daki büyük güçlüklerden biri, bilgi zaten zihinde olduğu için ya yeni bir şey öğrenilmeyecektir ya da ancak bilinen şey öğrenilecektir. Zira açık bir şekilde ona göre bilgi, bütüncül olarak bilinir ancak mutlak olarak bilinmez (Aristoteles, 1989b: 4).

Ona göre bilmek, ilm-i kıyas anlamında ispat vasıtası ile bilmektir. Ve bir şeyi bilmek sebeplerini bilmektir (Aristoteles, 1989b: 6,8). Görüldüğü gibi Aristoteles, bir nesnenin bilgisine vakıf olunabilmesi için izlenen yolda Platon'dan oldukça uzaklaşır. Nitekim Platon'da mutlak olan, ideler olduğu için bir şeyi bilmek zaten zihnimizde sahip olunan idelerin bilgisini hatırlamak ile gerçekleşir ve bu da mutlak bilgidir. Ancak Aristoteles'e gelince bilginin yolu duyulur olan tikellikten geçer. Onun için bilgi tikellerden tecrübe ile elde edildiği için mutlak bir şekilde şeyin bilgisine sahip olunamaz. Ancak bütüncül olarak şeyin neliğine nüfuz edilebilir. Evet, doğru ve kesin bilgiye imkân veren tek yol, kıyas/ispattır. Ancak kıyasın kurulabilmesi için gerekli olan veriyi elde etmek amacı ile izlenen başka bir öğrenme yolu daha vardır. Öz itibari ile Aristoteles'e göre insan için öğrenme ancak iki yol ile gerçekleşir. Birincisi, bütüncül ilkelerden yola çıkarak yapılan doğru bilgiye ulaştıran bahsi geçen ispat/kıyas iken diğeri bölümcüllerden hareketle tümevarımdır. Bilgi için iki yöntem gibi görünen ve öğrenmeye kaynaklık eden bölümcül ve bütüncül hallerden ikincisi de ancak bölümcüllerden yola çıkarak yapılan tümevarım ile elde edilir. Bu durumda tümevarımın doğasını anlamak, kesin bilgi sunan kıyasın esas unsurları olan öncülleri kavramak için gereklidir.

\subsection{Bilginin Doğası ve Tümevarım İlkesi}


Aristoteles`e göre, her bilişsel kanaat ya kıyastan çıkar yahut da tümevarım ile kazanılır. Düşüncenin iki temel biçimi tümelden tikele işlem manasında tümdengelim ve tikelden tümele doğru işlem anlamında da tümevarım- arasındaki fark1, birincinin doğa bakımından daha açık, daha akılsal ve daha zorlayıcı olmasında, ikincinin ise daha ikna edici, duyusal bakımdan daha anlaşılır olmasında görür. Mantıkçı sıfatıyla tümüyle kanıtlanmış doğru önermelerden oluşan ideal bir bilim düşlemiş olsa da, bir doğa bilimcisi olarak er geç kendileri kanıtlan(a)mayan birtakım kabuller, aksiyom ve hipotezlerden hareket etmenin kaçınılmaz olacağının (çünkü kıyaslar zincirinde geriye doğru gittiğimizde kendileri bu tür kıyasların sonucu olmayacak bir takım öncüllerle karşılaşırız) farkına varmış, bilimi meydana getiren bilimsel kıyasların, bilimsel akıl yürütmelerin bu ilkelerinin son tahlilde kıyasi olmayan bir yolla elde edilmesi gerektiğini kabul etmiştir ki, bu da duyuları hareket noktası olarak alan gözlem ve deney yöntemidir, yani tümevarım yoludur(Arslan, 2017: 95).

Aristoteles tümevarımı, tümelliği konusunda genel bir sonuca ulaşmadan önce bir tümelin bütün özel hallerinin teker teker incelenmesi olarak ele almak ister. Fakat doğada her varlık sınıfi ile ilgili olarak böyle bir tamsayımın yapılamayacağından dolayı, tamsayım kapsamına tümevarımın konusunu teşkil eden özel "bireysel" örnekleri değil, türsel (insan, at, katır gibi) örnekleri alır (Arslan, 2017: 96-97).

Tümevarımın içerdiği asıl güçlük ise, bir türün içine giren bireylerin sayısı sonlu veya sonsuz olsun, gözlemlediğimiz değişmez ve tekrarlanan niteliklerinin onların özlerini, doğalarını oluşturması için yeterli olmayacağı ile ilgilidir. Buradaki deneylerin çokluğu veya sıklığı, tümevarımın sonuçlarıyla ilgili bir kanaat ve inanç yahut psikolojik bir güven oluştursa bile, onun mantıksal kesinlik açısından geçerliliğinin teminatı yoktur.

Aristoteles bu sorunu, duyum işleminde duyu organının konusu olan duyusalla ilişkisinin araçsızlığg ve doğrudanlığ gibi, aklın veya ruhun bir örnek varlıkta o örnek varlığın bir örneğini teşkil ettiği türü bütünüyle ve herhangi bir akıl yürütme olmaksızın doğrudan kavramasına benzer bir çözümle açıklamaya çalışmıştır(Arslan, 2017: 99).Tümevarım, Matematikte olduğu gibi, formun düşüncede maddeden kolayca ayrıldığı durumlarda zihin, tek bir örnekte hakikatin algısından, onun bütün benzeri örnekler için geçerli olduğunu kavramaya geçmesidir.* Dolayısıyla, tümevarım esas itibariyle bir akıl yürütme işlemi değil, bir anlamda psikolojik olarak özel hallerin bütünsel bir görülmesini içeren doğrudan bir sezgi işlemidir (Ross, 2017: 76-77).

Kıyası oluşturan öncüllerin bizlere sunduğu veriyi elde etmenin yolu olan tümevarım için Aristoteles, tecrübenin zorunluluğunu vurgular. Onun için tümevarım yöntemi duyumu olmayan insanlar için imkânsızdır. Tümevarımdaki bütüne yani esas noktaya varmak için ihtiyacımız olan data ancak duyum aracılığı ile elde edilir. Onun duyu verilerinin nesnesi olan tikellere verdiği değeri daha önce belirtmiştik. Dolayısıyla ona göre her ne kadar tikeller önemli olsa da duyudan elde edilen veriler özel haller için geçerlidirler. Tecrübenin her bir ürünü müstakil olarak bir ilim oluşturmaz. Ancak her bir veriden ortak olarak çıkarılan genel fikir tümevarımı oluşturur ve tümevarım da ilim yani kıyas için gerekli olan bütüncüllerin bilgisini bizlere sunar.

Başka bir ifade ile onun açısından yalnızca duyum ile de ispat gerçekleşemez. Zira ispat için gerekli olan bütüncüller duyumun nesnesi değildirler. Bütüncüller tek bir nesneye yahut tek bir ana ait olmayıp tüm anları kapsadıklarından algılanmaları imkân dâhilinde değildir. Dolayısıyla duyum yolu ile ilim yapılması mümkün değildir (Aristoteles, 1989b: 78). Bahsi geçtiği üzere ilim için duyum yolu ile tümevarım gerekli ancak yeterli değildir. Zira duyum bölümcülleri algılar. Bölümcüllerden de tümevarım yöntemi ile bütüncüllere gidilir. Ve ilim ancak bütüncüller yolu ile yapılan ispat ile gerçekleştirilir.

Aristoteles, bu durumu şu şekilde ifade eder: "Tümevarmak, duyumu olmayan kimse için imkânsızdır, çünkü duyum hususi hallerde uyar, bunlar için de ilim olmaz, çünkü ilim tümevarım olmadan ne bütüncüllerden çıkarılabilir ne de duyum olmadan tümevarımla elde olunabilir (Aristoteles, 1989b: 50)."

Tümevarım vasıtası ile oluşturulan, doğru bilgiye götüren bir kıyas öncüllerden oluşup, bilgi ise sonuç kısmında yer alır. Şeyin ilmini, ancak sebeplerini bildiğimiz zaman elde edeceğimiz göz önüne alındığında, kıyastaki öncüller sonucun sebebi olarak karşımıza çıkar. Bilgi bakımından da önce geldiği için ondan daha çok bilinir. Bu öncelik aynı zamanda nesnenin var olduğunun bilgisine sahip olmak anlamına da geldiği için öncüller sonuçtan önce gelir (Aristoteles, 1989b: 7). Zira bir varlık hakkında doğru ve tutarlı bir şeyler söyleyebilmemiz için kurulan kıyastaki öncüllerin o varlık ile ilişkilendirilmesi, o varlığın var olduğunun ön kabulünün göstergesidir.

Aristoteles öncüllere ilk ilkeler diyecektir. Onun için, bütün bilgimiz kıyastan/ispattan gelip, kıyasta da bilinmek istenen şey yani sonuç daha çok bilinenlerden yola çıkarak elde edildiğine göre, ilk ilkeler denilen öncülleri sonuçtan önce bilmek yetmez, aynı zamanda daha iyi bilmek (zorunlu) gerekir. Bilgimizin ilk ilkelerden geldiği de göz önüne alındığında en iyi bildiğimiz işte bu ilk ilkelerdir (Aristoteles, 1989b: 8-9). Bu ilk ilkeler de belirtildiği gibi tümevarımın ürünü olan ilkelerdir ve biz bunları duyum sayesinde bilebiliriz.

Bununla birlikte hiçbir duyumu bilgelik olarak görmeyiz, çünkü onlar tek tekleri bilmenin en önemli yolu olsalar da hiçbir şeyin neden öyle olduğu hakkında bir şey söylemezler. Sözgelimi, ateşin neden sicak olduğunu değil, ama sadece sıcak olduğunu söylerler. O halde, bilgi (bilgelik) birtakım ilke ve nedenlere dair bilgi olmalıdır(Aristoteles, 2019a: 16).

Aristoteles neyi bilmek ve neyin bilinebilir olduğunu belirlerken bütünüyle Platoncu bir yol izler. Ona göre, varlıksal somut töz bir tikeldir, fakat tikeller gelip geçici özellik taşımaktadırlar. Bunlar maddeleri dolayısıyla varlık (var olma) ve yokluk (yok olma) ilkesine tabidirler. Bu nedenle kalıcı bilgi sağlayamazlar. Oysa bir tözün bilinemeyeceğini varsaymak bilim ve felsefeyi de inkâr etmek, en azından temellerini sarsmak manasına gelir. O halde, tözü bilmek, somut tikelde bulunan, ondan ayrılmaz olduğu halde onun gibi belirsiz olmayan bir ilke olmalıdır. Ne var ki, Aristoteles açısından bu ilkenin tümel olmasına da izin verilmez, çünkü bu sonuç Platoncu felsefeye tümüyle dönüş anlamını taşır (Denkel, 2011: 230). Aristoteles için, 
niteliklerin nihai taşıyıcısı olan töz, soyut bir biçim değil, somut bir bireydir. Örneğin belirli (tikel) "bu insan" ya da "şu at". Tözlerin bireyselliği ve somutluğunu tümellik düşüncesinden ayırmakta, tümelleri töz olarak kabul etmemektedir. O, Metafizik te bir tümelin (örneğin güzellik) bir töz olabileceğini reddeder, başka bir yerde de "İyilik" ideası ve "Mutlak İyilik" gibi kavramlara pek saygıyla bakmaz (Cottingham, 2015: 38).

O da hocası Platon gibi, tek teklerin bilgisinin olamayacağını ve bilginin her zaman tümellerin bilgisi olduğunu savunur (Cevizci, 2018: 94). Fakat bu tümel varlıklarda bulunduğu için değil, zihnin tikellerden ussal bir sezgi ve tümevarımlar ile tümel yönleri soyutlayabildiği için böyledir (Denkel, 2011: 111). Genel bir ilkeyi anlamaya çoğunlukla tikel örnek aracılığıyla ulaşıldığı gibi, soyutlamalarla uğraşmaya alışık olan zihinler tarafından örneklerin yardımı olmadan da, sezgisel bir yöntemle kavranabilirler (Russell, 2017: 121). Ona göre en temel ilkeler sezgi yetisi aracılığıyla kavranılır. Bu sezgiye deneysel sezgi de denilmektedir. Usun, algılanan bağlamındaki temel ilkeleri kavrayışı da bu yeti sayesindedir. Kısacası, bu sezgi deneye ilişkin ussal bir yetidir ki, deneyci ve ussal eğilimleri bir anlamda uzlaştırır. $\mathrm{Bu}$ yeti sayesinde tikeldeki tümel öğeleri soyutlayabilen zihin, tümevarımı da sezgi sayesinde gerçekleştirir. (Denkel, 2011: 125).

Dolayısıyla, Aristoteles'e göre kendisi ile bilim yapılan şeyler ancak tümellerdir. Bu doğrultuda ona göre tikeller bilimin nesnesi olamazlar. Zira her bir fert ile tek tek ilgilenilerek bir bilim yapılması oldukça zordur. Sözgelimi "İnsan, hayvandır" şeklinde bir tanım yapıldı ğı zaman kendinden daha geneli konuya yüklem yapılmaz ise müstakil olarak karşımızdaki "şu insanın” hayvan olduğu sonucunu elde edemeyiz (Aristoteles, 2019: 630). Bu doğrultuda ona göre doğru bilgiye götüren kıyas bütüncül öncüller ile başlar. $\mathrm{Bu}$ öncüllerden kastı söz gelimi fert olarak insan değil daha genel olan insanın alınması ile elde edilen öncüller yani temel ilkelerdir (Aristoteles, 1989a: 80).

Aristoteles'in bu yaklaşımı maddeden izole edilen tikelden yola çıkarak tümeli elde etmek maksadıyla gerçekleştirilen soyutlama düşüncesine yol açmıștır. Zira Platonda anlaşıldığı üzere tümel, tikelden soyutlanmanın aksine; tikele ontolojik olarak kaynaklık eden bizatihi reel ve müstakil varlıklar olan idealara karşılık gelir. Hocasının düşüncesine karşı çıkan Aristoteles`te ise bu durumda kullandığımız anlamda bir soyutlama söz konusudur.

\section{Onto-Epistemolojinin Doğası ve Soyutlama İlkesi}

Aristoteles'te tüm yüklemlerin konusu bireyler ya da türlerdir. Hiçbir kategori ilk özden çıkmaz çünkü kendisi de bir konu hakkında onaylanmamıştır. Oysa ikinci tözlerde tür, bireyler hakkında, cins ise türler hakkında onaylanmıştır. Tür ve bireyler hakkında onaylanmış ayrımlar için de benzer durum söz konusudur (Aristoteles, 2017: 27). Aristoteles felsefesinde her ne kadar türsel onaylanma durumu üstten alta gibi görünüyor ise de aslında söylenmek istenen önermede konu olan şeye yüklenen, konudan daha genel olduğu gibi, bireye yüklenen tür; türe yüklenen cins de benzer bir şekilde daha geneli oluşturarak onlara yüklenir. Burada "İnsan, hayvandır" ya da "Zeyd, insandır" önermelerine baktığımızda konuyu (tikel ya da tümel) daha çok mana içerir buluruz. Nitekim yüklemleme de alttan üste doğru gerçekleşir. Esas alınan töz ise, tözün tanımı için, bahsi geçen töz kaynak alınarak yapılan bir soyutlama olmalidir.

Felsefi literatürde soyutlama kavramı: 1. deneyim içerisindeki bir öğeyi, doğal kuruluşundan, yapısal ve fonksiyonel ilişkilerinden ayırarak, kendinde ve kendi başına düşünme işlemi, 2. bir-birlerinden başka bakımlardan farklılık gösteren nesnelerin ortak niteliğini düşünce yoluyla yakalayıp, genel bir kavram oluşturma, somut bir tarzda tek tek gözlemlenen özelliklerinden çok, birbirine benzeyen sonsuz sayıda durum ve ortamda gözlemlenebilen genel bir özelliği yakalama işlemi, 3. soyut bir kavramı bir dizi özellemesinden yalıtlayarak çıkartan bilişsel süreç, doğrudan ya da somut bir biçimde algılanamayan bir şeyi simgesel ya da kavramsal olarak temsil eden sözcüklere ulaşma, 4. tikellere ilişkin duyu algısından tümevarım yoluyla tümellere ulaştıran sezgisel bilgi yöntemi, bir dizi tikel şeyde ortak olanı inceleyerek tümel olana ulaşma sürecini ifade eder (Cevizci, 2002: 968).

Burada maddesel olmayanı, somut olandan izole etmek anlamında kullandığımız "soyutlama" kavramı ile ifade etmeye çalıştığımız zihinsel bir durumdur. Zira bunun için ortada Aristotelesçi anlamda bir töz olmalı ve ondan tözsel olanın özelliklerini belirten daha üstün ve daha genel bir varlık soyutlanmalıdır. Aristoteles'in epistemik hiyerarşisinde bulunan ferde yani tikele karşılık gelen töz, ondan soyutlanan ise daha geneli ifade eden ve maddesel olandan arındırılmış tümellerden tür ve cinslerdir. Bir önerme kurulduğunda, bir yarg1 için ifade ihtiyacı hissedildiğinde, öncelikli olan o hükmün konusunu temsil eden öznedir. Bahsi geçen özne tanımlandığında yüklemi olacak olan kavram ancak ve ancak onun tümelidir. Soyutlama denilen entelektüel eylem, Aristotelesçi anlamda söz konusu durumda devreye girerek töz ve tikel olan özneyi tanımlayan türü ve cinsi ortaya koyar.

Ona göre, yüklem hakkında kabul edilmiş olan konu hakkında da onaylanmıştır (Aristoteles, 2017: 22). Nitekim yüklem, ya onun içinde olması hasebi ile ya da onun hakkında onaylanmış olması sebebi ile bir açıdan konuya ilişir. Konuyu oluşturan fertler ya da türlerin, cinsler ile bağlantısı bu açıdandır. Cinsi elde etmek için yapılan soyutlamada, soyutlamanın nesnesi olan konudaki bölümler arasında tözsel öncelik ve sonralık bulunmaz. Nitekim "beyaz adam" denildiğinde, "beyaz" ya da "adam" geliş sırası itibari ile öncelik sonralık açısından birbirlerini izliyor görünseler de tözsel açıdan böyle bir durum söz konusu değildir.

Özne ve konunun kendisi adına kullanıldığı töz, Aristoteles sisteminde soyutlama için gerekli olan esas maddedir. Zira bahsi geçen bu eylem, reel varlıklar olan tözlerden, tümelin soyutlanması düşüncesini zihinlerde oluşturur. $\mathrm{Bu}$ nedenle bir soyutlanmanın yapılması için öncelikle töz kavramının idrak edilmesi gerekir. Bundan sonra töz ile ilişkili olan soyutlamanın işleyişi düşüncede daha açık bir hale gelecektir.

\subsection{Zihinsel Soyutlama}

Töz kavramı, toprak, su, ateş ve benzeri basit cisimler, hayvanlar, Tanrısal varlıklar gibi cisimler ve onlardan oluşan şeyleri anlatır. Tözün özelliği hiçbir şeye yüklem ol(a)mamas1, her şeyin ise, özne olarak kendisine yüklenebilmesidir. Aristoteles Metafizik adlı eserinde tözün 
iki anlamından bahseder: İlk anlamı ile töz, en son dayanak olup, başka hiçbir şeyin yüklemi haline getirilemeyendir; ikinci olarak ise, özü bakımından ele alınan bir şey olarak, (maddeden) ayrılabilen şeydir. Yani varlığın şekil ve formudur (Aristoteles, 2019a:289). Ona göre özne, mahiyet ve ikisinin birleşiminden oluşan şey anlamına gelen tözün karşılık geldiği bu anlamların dışında bir diğer anlamı daha vardır ki o da tümelliğe işaret etmesidir. Ancak tümel kavramından kastettiği şey Platoncuların ima ettiği gibi bir töze karşılık gelen şey değildir. Çünkü bir şeyin tözü, ona has olan (Aristoteles, 2019a:391), başka bir ifade ile özüne işaret ederek kendisinden başka bir şey olmayandır (Aristoteles, 2019a:242). Kendisi olandan kasit ise tikellerdir. Zira onun sisteminde cevherler yani tözler varlıklardan çıkarsandığı için töz, bireylerdir.

Aristoteles'e göre birden fazla töz olduğunu ifade edebiliriz. Nitekim ona göre fertler doğaları gereği töz olmakla birlikte bu tözler arasında ontolojik olarak bir fazlalık eksiklik ilişkisi yoktur (Aristoteles, 2017). Sözgelimi fert olarak at ya da fert olarak insanı ele aldığımızda at, insandan daha fazla ya da daha az töz değildir. Töz konusunda ontolojik hiyerarşi (eksiklik-fazlalık) daha önce de belirtildiği üzere birincil tözler fertler ve ikincil tözler dediğimiz tür/cins arasındadır.

Benzer olarak, bir töz kendi arasında daha fazla töz ya da daha az töz de olamaz. Mesela bir insan başka bir insandan daha çok ve ya daha az insan olamaz. Renkleri ele aldığımızda bu beyaz şuradakinden daha beyazdır denilebilir. Tek ve aynı bir şey için çokluk ve azlık tanımlaması da yapılabilir. Mesela beyaz bir şeyi göstererek "eskiden daha beyazdı" denilebilir. Ancak kendisi töz olan şeyler gibi, bir insanı göstererek "daha insandı" şeklinde çokluk azlık tanımlaması uygun değildir (Aristoteles, 2017: 28).

Aristoteles, nitelikleri varlığın "basit dalları ve görüntüleri" olarak tanımalar. Niteliklerin, ikinci tözler gibi (birinci) tözden bağımsız var olması imkânsızdır. Oysa tözler bireysel şeylerdir. Nitelikler açısından tözler;

-bireysel bir şey olarak töz,

-özsel doğa olarak töz ve

-sahip olan şey olarak töz şeklinde ele alınır (Ross, 2017:260261 ).

a. Tözün bireyselliği: töz nitelikler gerektirir, ancak bu nitelikler tözün kendisine muhtaç olan ve tözler dışında olan bir şeyler değildirler. Bilakis, nitelikler ancak bir tözde var olabilen bir soyutlamadır. Dolayısıyla, Aristoteles'in tözü bireysel bir şey olarak düşündüğü açıktır. Bu bireysel tözler niteliklere yataklık ettiği gibi, ikinci dereceden tözler için de temeldirler (Ross, 2017: 261). Tözün bireysel özelliği, hem nitelikler hem de ikinci dereceden tözler için onun ontolojik önceliğidir.

b. Tözün özselliği: bir şeyin ne olduğunu bilmek, onun niteliğini, niceliğini veya yerini bilmeye oranla daha kesin bir bilgidir. Çünkü bir şeyin ne olduğu hangi niteliklere sahip olduğundan çok daha önemlidir. Çeşitli niteliklere sahip olan bir şeyi o şey yapan şeyin ne olduğunu sorduğumuzda, onun özsel doğasına ilişkin bir şeyi sormuş oluyoruz. Tözün bu özelliği ise onun epistemolojik önceliğidir.

c. Tözün sahipliği: "Sokrates solgundur” önermesi üzerinde düşündüğümüzde şunu gözlemliyoruz; solgun olduğu söylenen şey ne solgunluktur, ne Sokrates`te solgunlukla birleşen bir niteliktir, ne de ondaki niteliklerin toplamıdır. Sokrates, bu niteliklere sahip olan, onlar için dayanak olan ve niteliklerin kendisinde birleştiği şeydir. Tözün sahipliğinin anlamı da budur (Ross, 2017: 262).

\subsection{Nesnel Soyutlama}

Zihinsel soyutlamadan farklı olarak nesnel soyutlama, varlığın maddesel boyutu ile ilişkilidir. Yani buradaki soyutlama artık madde ekseninde gerçekleştirilir. Soyutlanan öz, soyutlamanın nesnesi olan maddeden elde edilir. Aristoteles açısından üç türlü nesnel soyutlama yapılabilir;

\section{Madde/Somut Soyutlamas1}

Aristoteles'e göre "yer", her cismi saran ilk şeydir ve bu nedenle o aynı zamanda somut nesne için bir sınırdır. O aynı zaman da büyüklük ve büyüklüğün maddesi onunla belirlenen, sınırlanan yer her bir nesnenin biçimi ve şekli diye düşünülebilir. Çünkü her bir nesnenin sınırı budur. $\mathrm{Bu}$ açıdan o, aynı zamanda nesnenin biçimidir. Büyüklüğün yerini dolduran şey olarak da düşünüldüğüne göre yer "madde" demektir. Bir küreden sınırı ve biçimsel özellikleri atıldığında geriye kalan şey maddeden başkası değildir (Aristoteles, 2019b:141). Aristoteles`e göre, madde, madde olarak edilgendir. Çünkü ateş sıcağı maddede taşır; eğer sıcak müstakil bir şey olursa, bu herhangi bir etkiye maruz kalmaz (Aristoteles, 2019c: 53).

Madde ise, hiç bir zaman saf haliyle bulunmaz, mutlaka bir form alarak mevcut olur. Aynı şekilde, mahiyet ve salt form olmayan, bununla birlikte bireysel varlığa sahip olan her şeyin maddesi vardır (Aristoteles, 2019a:386). Seyreklikyoğunluk, doluluk-boşluk, varlık-yokluk, yukarı-aşağı, önarka, doğru-eğri gibi türünden karşıtları ilk ilkeler olarak kabul edenlerin aksine, Aristoteles seyrekliğin yoğunluğa etkide bulunamayacağını, sevginin nefretle birleşemeyeceğini ve ayrışamayacağını savunarak, bunlar arasındaki bağlantıyı (olumlu ve olumsuz) sağlayacak olan bir üçüncü ilkeyi varsayar. Artı, bu karşıtlar sıfatlar olduğuna göre, sıfatların kendisinde bulunacağı bir tözü varsayar. Bu tözün başka bir töze karşıtlığı düşünülemeyeceğine göre, bu tözün birinciliği (önceliği) ortadadır. O halde, her şeyin tek bir maddi dayanağı olduğunu kabul etmek gerekmektedir. Ne var ki, bu maddi dayanak dört unsurdan (hava, su, toprak, ateş) biri de olamaz. Olsa olsa bunların arasında aracı bir şeye özdeş olan başka bir şey olur (Ross, 2017: 113).

Madde, Aristoteles açısından Ay altı dünyaya ait olan bir nesnedeki değişmenin gerektirdiği şey olduğundan uzaysal (yer deyişimi, hareket gibi), niteliksel (soğuk suyun 1sınması, sağlıklı insanın hastalanması gibi), boyutsal (büyüme ve küçülme - çocuğun beslenme suretiyle büyümesi gibi) ve varoluşsal/yokoluşsal (bir insanın varlığa gelişi ve ölümle ortadan kalkması gibi) değişimlerin de üzerinde cereyan ettiği zemindir. Dolayısıyla madde (hyle) bir anlamda yersel madde veya yer değişmenin maddesi, nitelik değiştirmenin maddesi, boyut değiştirmenin maddesi, oluş ve yok oluşun maddesidir ve bu madde yatakları arasında bir hiyerarşi söz konusudur. Şöyle ki, ikinci birinciyi, üçüncü de ikinciyi, dördüncü ve üçüncü ise birbirlerini gerekli kılar (Ross, 2017: 263). 
Aristoteles`in asıl ilgisi bu değişmeler içerisinde "tözsel değişme" olarak gördüğü sonuncusu, yani oluş ve yok oluş değişmesidir. Çünkü burada bir yer değişme, nitelik değiştirme, büyüme ve küçülme değil, "tözün kendisinde" meydana gelen bir değişme söz konusudur (Arslan, 2017: 140). Madde, dayanak ve değişme arasındaki ilişki şöyledir:

“Güneşe bırakılmış bir sürahi içindeki su 1sınır. Şimdi bu ısınma olayı neyi gerektirmektedir? Ortada belli bir niteliği olan şey vardı ve bu şey başka bir şeyin etkisi altında niteliğini kaybederek, başka bir nitelik kazandı ve böylece başkalaştı. Ortada soğukluk niteliğini kaybederek yeni bir nitelik kazandi. Kısaca burada değişen şey nedir? Soğukluğun kendisi mi? Bunun mümkün olmadığı açıktır. Bir niteliğini kendisi değişerek başka bir şey, kendisinin zıddı olamaz. Değişen şey soğukluk niteliği değil, soğukluk niteliğini kabul etmiş olan, şimdi ise bu niteliği kaybederek sıcaklık niteliğini kazanmış olan sudur..." (Arslan, 2017: 140).

Buradaki değişimin iki temel unsuru söz konusudur: İlki değişen niteliğin kendisidir, yani yüklemdir. İkincisi ise bu niteliği kabul eden bir şey, özne veya dayanaktır (substratum). Aristoteles, üzerinde değişikliğin meydana geldiği, değişmeyi kabul eden şeye madde, bu maddenin, öznenin veya dayanağın üzerine gelen ve birbirlerini izleyen niteliklere ise genel anlamda form adını vermektedir (Arslan, 2017: 141).

Aristoteles'in maddesi olmayan salt formları kabul etmesinde hocası Platon 'un etkisi varsayılır. Zaten Tanrı ve saf tözleri maddesi olmayan varlıklar olarak görmesi de, bu düşüncesi ile tutarlılık arz etmektedir. Ne var ki, maddesi olmayan saf formlar düşüncesinden hareketle, formu olmayan, nitelik kazanmamış, herhangi bir belirleme almamış salt bir madde, ilk madde, bireysel ve bağımsız bir asli maddeyi(prima materia) tanımlama Aristoteles açısından imkânsızdır (Arslan, 2017: 142). Dolayısıyla, maddenin temel özelliği, forma sahip olmadan belirsiz olmasıdır. Formun kendisine vereceği belirleyici özellikleri almadan madde hiçbir şey değildir. Kısacası, maddeyi sıcaksoğuk, canlı-cansız, akıllı-akılsız gibi yapan formdur.

Maddeyi belirsiz olarak tanımlama Aristoteles`e, duyusal varlıkların maddesinden söz edebildiği gibi, duyusal olmayan matematiksel varlıkların da maddesinden söz etme imkânı sağlamıştır. İnsanın maddesinin onun bedeni olması, bir üçgenin üç açıdan meydana geliyor olmasının onun formunu oluşturması gibi, formun mutlaka bir maddeyle birlikte olmasının zorunluluğundan hareketle üçgenin maddesinden (belirsiz de olsa) söz etmenin mümkün olduğunu kabul eder. Aristoteles`e göre bu madde uzaysal uzam yahut akılsal madde olacaktır. Ona göre, geometrik cisimler, cisim olarak tanımlarını oluşturan formlar veya doğayla birlikte, bu formlar veya doğalarının içinde gerçekleştikleri bir maddeyi yani uzam denen zihinsel maddeyi gerektirirler (Arslan, 2017: 145-146). Dolayısıyla, varlık hiyerarşisinin en üstünde maddesi olmayan Saf Formu (Tanrı) kabul edebiliriz, fakat bu hiyerarşinin en altında salt bir maddenin bağımsız, bireysel ontolojik varlığından bahsedemeyiz, ancak zihinde, kuruluk-yaşlık, sıcaklıksoğukluk gibi niteliklerinden soyutlanmış bir varlığından bahsedebiliriz.

Özdek/Dayanak Soyutlaması
Aristoteles için somut olan nesne, (bireysel olan) özdekle, (tümel olan) formun bileşiminden başka bir şey değildir. Çünkü nesnenin büyüklüğünün yayılımı olan özdek, yayılımdan formu kaldırınca ortaya çıkan (ortada kalan) şeydir. Dayanak (1) hareket noktası, form (2) ulaşılması gereken sondur. Fakat bu hareketi ve değişimi sağlayan üçüncü bir nedene ihtiyaç vardır $\mathrm{ki} \mathrm{o}$ da formun yoksunluğudur (3).Madde değişen şey, form kendisine dönüşülen şey, yoksunluk ise değişenin, kendisine dönüşülene ermek için elde etme ihtiyacıdır. Fakat bu basit yoksunluk anlamında değil, dayanaktaki yoksunluk anlamındadır. Aynı şekilde hiçbir şey basit var olandan meydana gelmez, varlığa gelecek olan özel şeyden başka şey olarak göz önüne alınan var olandan varlığa gelir (Ross, 2017: 114). Anlaşılacağı üzere dayanak sayısal olarak birdir, fakat o aynı zamanda olacağı, olması gereken şeyi de içerdiği için ikilik özelliği taşımaktadır. Fakat Aristoteles yoksunluğu madde gibi bir ilke olarak görmez. Çünkü yoksunluğun bir şeyin doğasında, varlık bakımından içerilmiş bir şey olmadığının da bilinmesi gerekiyor. Bir forma sahip olmak, fiilen o formun karşıtından yoksun olmak anlamına da gelir (Ross, 2017: 114-115).

Dayanak ise, ne meydana gelen, ne de yok olan şeydir. Meydana gelemez, çünkü bu durum kendisinden meydana geldiği varlıktaki dayanağı gerektirir ki, bu sonsuza kadar süremez. Oysa varlık var olamaz, varlığa getirilemez, o hep vardır. Yok da olamaz, çünkü yine varlıkta devam eden bir dayanağın olmasını gerektirir ki, bu durum var olmadan önce "var olmak", yok olmadan önce "yok olmak" gibi tuhaf bir duruma neden olur (Aristoteles, 2019b: 49).O zaman özdeği aşağıdaki ilkelerle tanımlamak mümkündür;

1. Özdek, üzerinde değişimin gerçekleştiği ilkedir.

2. Tikellerin bireyleşim ilkesidir.

3. Tözün potansiyelini içinde barındıran ilkedir.

4. Bir şeyin” kendisinden oluştuğu şeydir.

Form/Öz Soyutlaması

Aristoteles`e göre, nesnedeki duyusal maddeyi (nitelikleri), büyüklük ve küçüklüğü (boyut), biçim ve şekli ve nihayet uzamı veya akılsal maddeyi soyutladığımızda geriye kalan salt formdan başkası değildir (Ross, 2017: 265). Varlıkta madde, özdeğin potansiyelini temsil ettiği kadar, form da aktüaliteyi temsil eder. Formu madde içinde olmayan varlıklar, etkin şeyler arasında olup herhangi bir etkiye kapalıdırlar. Yani maddesiz formlar etkindirler, ancak edilgin olamazlar. Maddesi olan formlar ise edilgindirler. Zira her bir zıtlık çiftinin aşağı yukarı aynı maddeye sahip olması gerekmektedir (Aristoteles, 2019c: 51).

Form-madde ilişkisinde maddenin forma kadarki sınırı, formun da maddeden hareket noktasının çizilmesi gerekmektedir. Tanımın tümellerle yapıldığı malumdur. Formlar da alt-türler* olduklarına göre, formların "içerisinde" ne kadarının maddeye, ne kadarının forma ait olduğunu belirlemek kaçınılmaz gibi gözüken bir durum olsa da, bunu yapmak güçtür. Bir daire tunç, taş ve tahta gibi farklı maddelerden olabildiği halde, dairenin onlarınkinden ayrı bir varlığa sahip olmasından hareketle, bunların hiçbirisinin dairenin özü içerisinde yer almadığı söylenebilir. Fakat her zaman aynı madde ile beliren formlar söz konusu olduğu zaman, aynı maddeyi formun tanımı içerisinde 
değerlendirmek de gerekmiyor. Örneğin, insanın formu bize her zaman et, kemikler ve benzeri kısımlarla birlikte görünür. $\mathrm{Bu}$ nedenle, "onlar formun, dolayısıyla tanımın kısımları mıdır? Yoksa böyle değildirler de daha çok maddenin kısımları mıdır? İnsan formu başka maddelerle birlikte görünmediği için, bu ayırımı yapma gücüne sahip değiliz"(Aristoteles, 2019:384). Fakat aynı nedenlerden hareketle, bütün şeyleri idealara indirgemek ve maddeyi ortadan kaldırmak da gerekmiyor. Daire örneğinde olduğu gibi, maddeye (tunç, taş, tahta vb.) bağlı olmadan tanımlanabilen bir daireden bahsedebiliyorsak da, örneğin insanı, kısımları olmadan tanımlamak imkânsızdır. Çünkü insanın gerçek anlamda kısmı olan el değildir, işini yapma gücüne sahip olan, canlı eldir. Cansız el insanın parçası değildir. Dolayısıyla, maddenin kendisi ancak form ve işlevle insanın parçası olduğunda, madde ile form arasında çözülmez bir bağ söz konusudur (Aristoteles, 2019a:386).

Tözün form olduğunu temellendirmek adına Aristoteles, tözün doğasının ne olduğunu belirlemeye çalışır ve hareket noktası olarak da "neden" kavramını seçer. Çünkü bir tözü tanımlarken, "bir şeyi o şey yapan şey" olarak belirtiriz. Dolayısıyla, bu durumun "niçin" sorusunun yanıtını da içermek zorunda olduğu açıktır. Aristoteles, "Gök niçin gürler?" sorusunun, "Bulutlarda niçin bir gürültü çıkar?" sorusuyla aynı kapıya çıkacaklarını savunarak, burada aslında aranan şeyin formel neden, ya da form olduğunu saptar: "O halde, burada aranan şeyin, neden olduğu açıktır. Şimdi "neden" mantıksal bakımdan özdür; Öz de bazı durumlarda ereksel nedendir"'(Aristoteles, 2019a:407-408).

\section{Sonuç}

Sonuç olarak, Aristoteles ontolojik önceliği var olma açısından başkasına ihtiyaç duymama durumu olarak, tözle ilişki bağlamında tanımlar. Onun "düşüncede var olma" açısından bütünü önceleyen kavramlar görüşü ise mantıksal önceliği teşkil etmektedir. Tek bir varlık değeri kabul edip bunların tümünü de idealarda olan bir niteliğe indirgeyen Platon un aksine, Aristoteles (birincil) tözlerin yanı sira özlerin (ikincil tözler) de yadsınmaması gerektiğini savunmaktadır. Tümelleri inkâr etmeyerek, tam tersine onu bilimin vazgeçilmez malzemesi olarak düşünen filozof, bilginin hareket noktası olarak tikelleri, her şeyin kendisine yüklenebileceği, fakat kendisi asla yüklem olamayacak olan tözleri almaktadır.

Bunun yanı sira o, Platoncu idealar kuramından ilhamla da bilimin tikellerle değil, tümellerle yapılabilir olduğunu, zorunlu bilginin tümel özellikler taşıdığını savunur. Tümelleri inkâr etmez, fakat onların töz olmadığının da altını çizer. Ontolojik hiyerarşide birincil tözleri temel, ikincil tözleri ise onların içerisinde "içerilmiş" formlar olarak kabul eden Aristoteles, nesnel/fiziksel dünyayla ilgili "konuşurken" töz-nitelik bağlamında birincileri merkeze alır gözükürken, zihinsel/bilişsel durumlar söz konusu olunca özne-yüklem ilişkisine ağırlık vermektedir.

Bilginin doğasını, onun hareket noktasını oluşturan tikellerden başlayarak, onların çeşitli şekillerde soyutlamalarından oluşan tümevarım ve genel hükümlerden çıkarımla kazanılan zorunlu bilgi (kıyas) olarak tanımlayan Aristoteles, tümevarımın içerdiği "tüme var(a)mama" sorununu "aklın ve ya ruhun, varlığın bir örneğini teşkil ettiği türü bütünüyle ve herhangi bir akıl yürütme olmaksızın doğrudan kavramasına benzer" bir durumla çözmeye çalışmıştır.

Her bilişsel kanaatin ya bir kıyasa, ya da tümevarıma dayandığını savunan filozof, tümevarım yöntemini sezgisel aklın tikellerden hareketle, yine tikellerde içerilmiş olan tümele ulaşması olarak tanımlar. $\mathrm{Bu}$ durumda tümevarım yönteminin temel araçlarının gözlem ve deney olacağı açıktır. Nitekim tümevarım duyum olmadan yahut duyuları olmayanlar için imkânsızlaşmaktadır.

Soyutlama ilkesine gelince, Aristoteles ontolojik ve epistemolojik yaklaşımlardan hareketle, birincil ve ikincil tözler bağlamında zihinsel/epistemik ve nesnel/ontolojik özelliklerini belirlemiştir. Bu nedenle, zihinsel soyutlama meselesini tözün bireyselliği, tözün özselliği ve tözün "sahipliğii" olarak üç şekilde değerlendirdik. Nesnel soyutlama ilkesini Aristoteles`in madde-form düşüncesinden hareketle de madde/somut, özdek/dayanak ve form/öz şeklinde açıklamaya çalıştık. Bitirirken, yazımızda çeşitli vesilelerle belirttiğimiz üzere, tümevarım ve soyutlama düşüncesini Aristoteles in eserlerindeki birincil töz ve ikincil tözün tanımı ve önemi konusundaki birtakım belirsizliklerin üstesinden gelerek anlatmanın zorluğunu da teslim etmemiz gerekir.

\section{Kaynakça}

Aristoteles. (2019a). Metafizik, Ahmet Arslan (Çev.), İstanbul: Divan Kitap.

Aristoteles. (2019 c). Oluş ve Bozuluş, Y. Gurur Sev (Çev.), İstanbul: Pinhan Yayıncılık.

Aristoteles. (2019b). Fizik, Saffet Babür (Çev.), İstanbul: Yap1 Kredi Yayınları.

Aristoteles. (2017), Kategoriler-Önermeler, Furkan Akderin (Çev.). İstanbul: Say Yayınları.

Aristoteles. (1989c). Organon I: Kategoryalar, H. Ragıp Atademir (Çev.), İstanbul: M.E.B. Yayınları.

Aristoteles. (1989a). Organon III: Birinci Analitikler, H. Ragıp Atademir (Çev.), İstanbul: M.E.B. Yayınları.

Aristoteles. (1989b). Organon IV: İkinci Analitikler, H. Ragıp Atademir (Çev.), İstanbul: M.E.B. Yayınları.

Aristoteles. (2018). Hayvanların Oluşumu Üzerine Furkan Akderin (Çev.), İstanbul: Say Yayınları.

Arslan, A. (2017), İlkçağ Felsefe Tarihi: Aristoteles, İstanbul: Bilgi Üniversitesi Yayınları.

Cevizci, A. (2018). Bilgi Felsefesi, İstanbul: Say Yayınları.

Cevizci, A. (2002). Felsefe Sözlüğü, Ankara: Paradigma Yayınlar1.

Cottingham, J. (2015). Akılcılık, Bülent Gözkan (Çev.), İstanbul: Dergah Yayınları.

Denkel, A. (2011). İlkçağda Doğa Felsefeleri, İstanbul: Doruk Yayımcilık.

Ross, D. (2017). Aristoteles, Ahmet Arslan (Çev.). İstanbul: Kabalc1 Yayınları. 
Russell, B. (2017). Felsefe Sorunları, Vehbi Hacıkadiroğlu (Çev.), İstanbul: Say Yayınları.
Platon. (2015). Timaios, Furkan Akderin (Çev.), İstanbul: Say Yayınları. 